\title{
The influence of practicing spiritual tourism on the environment in Chau Doc - An Giang - Viet Nam
}

\author{
Ta Duy Linh, Duong Duc Minh*
}

\begin{abstract}
Chau Doc is a city of An Giang province in Mekong delta of Vietnam. This city has Sam Mountain with cultural and spiritual values. One of the highlights of the local spiritual culture is Ba Chua Xu (Lady Territory) shrine. Every year, this spot attracts between 3 and 5 million visitors. With a great number of tourists, the practicing of spiritual tourism has had an impact on the natural and cultural-social environment. The influence of stakeholders on the environment (nature and humanity) through the enjoyment and provision of tourism services. Stakeholders have involved in tourism activities in Chau Doc include: local authorities, service providers (food and beverage, accommodation, transportation,...) and tourists. The practice of spiritual tourism is different from other types of tourism. Spiritual need has overwhelmed need to enjoy tourist services. With the expectation of improving economic benefits for the locality, tourism services are increasingly invested and supplemented. When economic interests are concerned, the issues of preserving natural values and cultural-social are limited, creating threat that could hurt the environment in Chau Doc. Therefore, the exploitation and development of spiritual tourism creates certain influence on the local environment. The study of the effects of spiritual tourism practice is necessary in the present context. Through field surveys, in-depth interviews with stakeholders and observations in local spiritual culture festivals from September 2016 to June 2018, this article describes and analyzes characteristics of practicing spiritual tourism in Chau Doc. Since then, the authors find out the influence of practicing spiritual tourism on natural and cultural - social environment of locality. At the same time, the authors provide some suggestions for exploiting spiritual tourism in Chau Doc.
\end{abstract}

Key words: practicing spiritual tourism, impact on environment, Chau Doc - An Giang - Viet Nam

\section{INTRODUCTION}

The University of Social Sciences and Humanities, VNU-HCM

\section{Correspondence}

Duong Duc Minh, Email: duongducminh@hcmussh.edu.vn

\section{History}

- Received: 30-11-12018

- Accepted: 04-4-2019

- Published: 28-6-2019

DOI :

https://doi.org/10.32508/stdjssh.v3i1.509

\section{Check for updates}

\section{Copyright}

(C) VNU-HCM Press. This is an openaccess article distributed under the terms of the Creative Commons Attribution 4.0 International license.

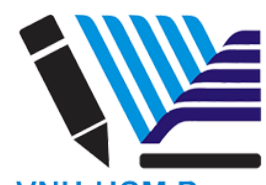

VNU-HCM Press

\section{Methodology}

Through the process of collecting secondary materials and field surveys in Chau Doc - An Giang from from May 2016 to January 2018, we use research methods: in-depth interviews (tourists, local community, representatives of the governmental authorities on tourism management, representatives of travel companies) in Chau Doc - An Giang. Then, we integrate the interview results into analytical content of the article.

\section{Researching approach}

In this paper, we analyse the influence of practicing spiritual tourism on the environment from anthropological perspective with sustainable tourism development thinking.

In 1950, the concept of development was used to look at comparisons between developed and developing countries $^{1}$. At early stage, development is almost considered economic growth. In fact, economic growth is not only the result that can lead to good quality of life. Apart from economic growth, other indicators of environment, society and culture must be ensured. From that, the movement of economic development associated with environmental protection has been formed. At the same time, the issue of balancing economic development with culture and society is concerned and complementary. This is the premise to Brundtland report was born in $1987^{2}$. This report introduces the concept of sustainable development in a formal way.

Sustainable development has become a global discourse. Because the orientation of sustainable development is to justify and overcome the limitations of development that humanity is confronted with. Sustainable development is a shift in approach that emphasizes harmony rather than conflict. Sustainable development towards the balance of pillars including economy, natural environment, society, culture and management of government.

The anthropologist, as a researcher, will have the strength to analyze the discourses of sustainable development from "poststructuralism"; identify the capacity of local communities (especially ethnic mi- 
nority groups) when approaching and implementing policies; analyze changes and make forecasts that hurt the local community; forecast conflicts of rights and interests of stakeholders; recommend policies that are feasible and suitable for sustainable livelihoods towards poverty reduction, gender equality, etc.

In the field of tourism, the concept of sustainable tourism appears on the basis of improving and upgrading the concept of "soft tourism" in the $1990 \mathrm{~s}^{3}$. Since then, this concept has been launched by many organizations and individuals, and is actually gaining widespread attention over the word.

According to World Tourism Organization sustainable tourism is: "Tourism that takes full account of its current and future economic, social and environmental impacts, addressing the needs of visitors, the industry, the environment and host communities"a.

Thus, sustainable tourism should:

1. Make optimal use of environmental resources that constitute a key element in tourism development, maintaining essential ecological processes and helping to conserve natural heritage and biodiversity.

2. Respect the socio-cultural authenticity of host communities, conserve their built and living cultural heritage and traditional values, and contribute to inter-cultural understanding and tolerance.

3. Ensure viable, long-term economic operations, providing socio-economic benefits to all stakeholders that are fairly distributed, including stable employment and income-earning opportunities and social services to host communities, and contributing to poverty alleviation ${ }^{4}$.

The discourse of sustainable tourism development has a great influence on the planning, organization and management of tourism in Vietnam. The Politburou's Resolution 08-NQ/TW on developing tourism has been concluded: "sustainable tourism development; preserving and promoting the cultural heritage and traditional values; protecting natural environment, resolving the problem of labour, employment and social security" ${ }^{2}$.

From the anthropological approach, this paper focuses on analysing the discourse of sustainable tourism development; attitude, behaviour and practice of stakeholders in the sustainable tourism development strategy in Vietnam with typical example is Chau Doc - An Giang.

\footnotetext{
${ }^{\mathrm{a} h t t p: / / s d t . u n w t o . o r g / c o n t e n t / a b o u t-u s-5 ~(J u n e ~ 22, ~ 2018) ~}$
}

\section{RESULTS AND DISCUSSION}

\section{Overview of Chau Doc - An Giang}

In the painting of An Giang tourism, Chau Doc is seen as a prominent tourist center of the province. The key of tourism development in Chau Doc is historical relics of Sam Mountain.

In the development strategy of Vietnam's tourism until 2020 and vision to 2030, the Ministry of Culture, Sports and Tourism has oriented development of The System Mausoleum Temple Sam Mountain become the national tourism site.

Especially, the place that attracts more tourists is $\mathrm{Ba}$ Chua Xu shrine (Lady Territory shrine) - dubbed "chicken that lays golden eggs" for An Giang tourism. Sam Mountain with a total area of 2 hectares, where each year attracts about 5,300,000 tourists and pilgrim visits ${ }^{\mathrm{b}}$. Visitors and sources of revenue in 2014, 2015 as follows: 2014: 4,200,000 passengers, collecting entrance fees was 19.96 billion VND; 2015: 4,274,800 passengers, collecting entrance fees is 30,411 billion $\mathrm{VND}^{6}$.

The peak season of spiritual tourism in Sam Mountain takes place from after the Tet lasts until the end of April lunar calendar. Since this is the season to visit $\mathrm{Ba}$ Chua $\mathrm{Xu}$ shrine. About 3.000.000 - 4,000,000 tourists come to visit Sam Mountain during this time. Ba Chua Xu shrine is a tourist attraction featured psychic in the South of Vietnam. On peak days, Sam Mountain can welcome up to 72,000 passengers" (Results of interviews representatives of the Manager of Toursim Office, Department of Culture, Sports and Tourism of An Giang on at 8:30 on 09 Jun 2018)

Therefore, the capacity on peak days in Sam Mountain is 72,000 passengers / 2 hectares (72,000 passengers / $20,000 \mathrm{~m}^{2}$ ) that means approximately 3.6 passengers $/ \mathrm{m}^{2}$. This figure has exceeded the capacity of tourist standard. Thereby can imagine Sam Mountain relics under intense pressure of visitors at this time. This research should be considered directly the administration to reduce pressures and harms the monument

\footnotetext{
${ }^{b}$ Results of interviews representatives of the Department of Culture, Sports and Tourism of An Giang on at 8:30 on January 2018
} 
system towards conservation and spiritual nature. At present, $\mathrm{Ba}$ Chua Xu shrine is in the peak season, the phenomenon of unsettled purchases, theft, loss of security and order - beauty has seriously affected the image of tourism, land and local people in the eyes of visitors. Capacity of Sam Mountain in the peak season can be imaged by follow Figure 1 .

Besides, although the visitors have positive and encouraging signs in terms of increasing quantity, but the behavior of tourism services consumption (accommodation, food, tours of nearby attractions) less rich and varied that leads to payment for spiritual tourism when visit Sam mountains is not high ${ }^{\mathrm{c}}$. As tourist coming to Sam Mountain is mainly due to the spiritual needs of visitors, however, revenues from tourists are incommensurate. One of the reasons for the above situation is the power of supply activities and tourism services to visitors coming to the mountain spirit Sam in particular and An Giang in general still have not yet to use, combine to exploit the other tourist resources available in local communities this spiritual tourism sites.

\section{Analysing the impact of tourism develop- ment to environment in Chau Doc - An Gi- ang}

Firstly, we analyze the first pillar of sustainable tourism development at Chau Doc - the local policy. We chose two document to debate are Decision approving the master plan for tourism development of An Giang province from 2014 to 2020 and vision to $2030^{\mathrm{d}}$ (document 1) and Construction plan and process to upgrade Sam Mountain to become the national destination ${ }^{\mathrm{e}}$ (document 2). In particular, document 1 mentions "tourism development in An Giang towards sustainable, professional and modern" 7 . Document 2 mentions "tourism development is closely linked to the development of trade and preservation of national culture, identity in order to actively contribute to the sustainable economic development of the locality" ${ }^{8}$. Two documents clearly emphasize the objective of sustainable tourism development. Thus, the discourse on sustainable tourism development has a great influence on the orientation of tourism development in An Giang in general and Chau Doc in particular.

Next, we analyze the actual development of tourism in Chau Doc. Sam mountain is the core of tourism development in Chau Doc. The parties involved in the

\footnotetext{
${ }^{c}$ Depth interview with Leaders of the Department of Culture, Sports and Tourism An Giang on 9 June 2016

${ }^{\mathrm{d}}$ By The People's Committee of An Giang Province issued in 2014

${ }^{\mathrm{e}} \mathrm{By}$ The Management Board of Sam Mountain cultural relics and tourism issued in 2014
}

exploitation and the development of spiritual tourism at Sam mountain culture space including: tourists; the State management agencies on tourism; the management board of spiritual culture - religious relics; service facilities to serve the needs of the tourists (transportation, restaurants, inns, hotels and establishments providing offerings, souvenirs,...) and the locals (hawkers, motorbike taxi, "service brokers",...). Tourists are required to pay for the services performed during the spiritual tourism activities, from transportation; storage; food and drink; worship, offerings and other services. The remaining parties involved are the persons receiving the economic benefits from the tourism. With the exploitation and development, the tourism seems to facing overload which reduces the spiritual and cultural values and creates a negative to the tourists. Service for tourist is illustrated by Figure 2.

Identifying the available potential of this travel complex, the local government has made plans to exploit the elements of culture, arts, spirit to serve tourism in the overall travel activities of the province. An Giang Province has organized the review, statistics to manage 115 temples, pagodas, hermitages. At the same time, it calls for investment in the key projects such as moving the current gardens in Sam Mountain to the new location and adding new items to build a complex (a size of 9 ha, total investment of 139 billion VND); Truong Gia Mo lake-bed tourist area (a size of 10 ha, total investment of 53 billion VND); Sam Mountain entertainment complex (a size of 70 ha); Chau Doc City entertainment and resort area (a size of $70 \mathrm{ha}$ ); 3- 4-star floating hotel on Chau Doc River (size of 0.8 ha, total investment of 53 billion VND), and Sam Mountain Cultural Park. At this park, an 81-meter statue of Buddha Shakyamuni basing on Sam Mountain would be built with a cost of 255 billion VND (the groundbreaking ceremony was on 05 March 2015) which is expected to form the key spiritual destination of Vietnam. (Result of interview with The Management Board of Sam Mountain cultural relics and tourism in June 2018)

In the process of building new architectural works for tourism development in the mountain Sam, there appears some constructions which are not in accordance with the traditional cultural values of the locality. In particular, the construction of a new statue of Ba Chua $\mathrm{Xu}$ in early 2018. Soon after, this statue was asked to remove. The new statue of $\mathrm{Ba}$ Chua $\mathrm{Xu}$ is illustrated by Figure 3.

Therefore, spiritual values are the important cultural resources which have been contributing to the economic development of tourism in Nui Sam relics 


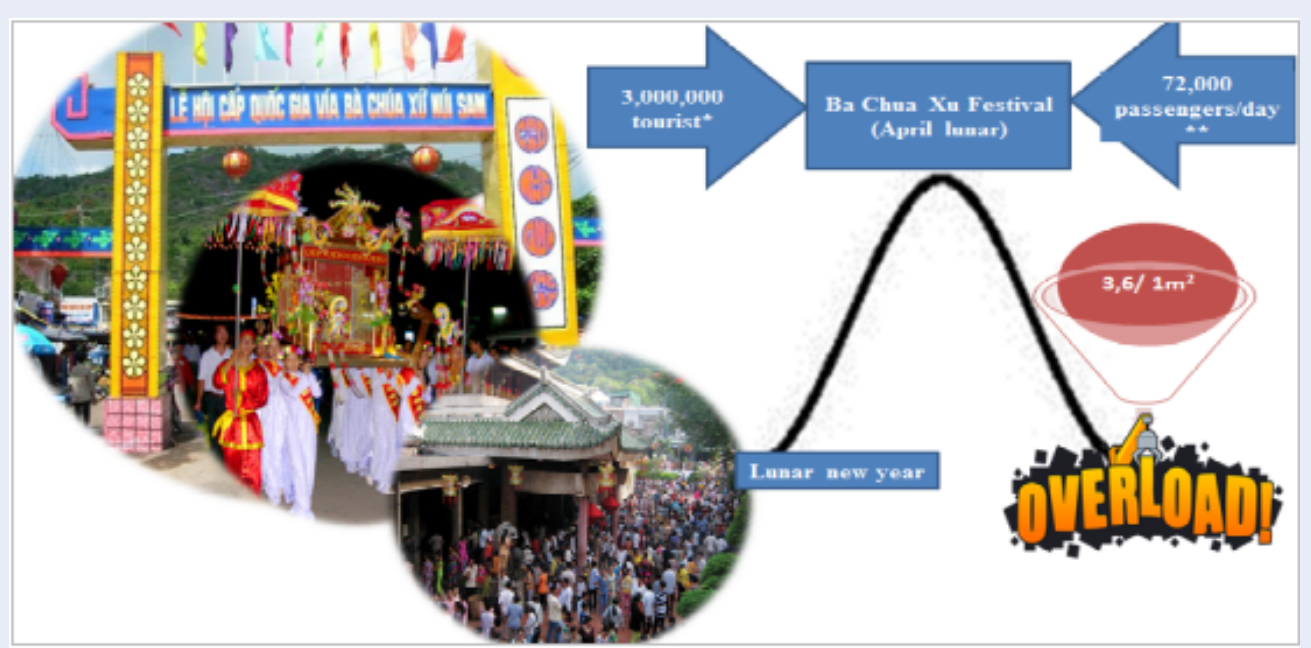

Figure 1: Capacity of Sam Mountain in the peak season. Source: Ta Duy Linh - Duong Duc Minh, 2018
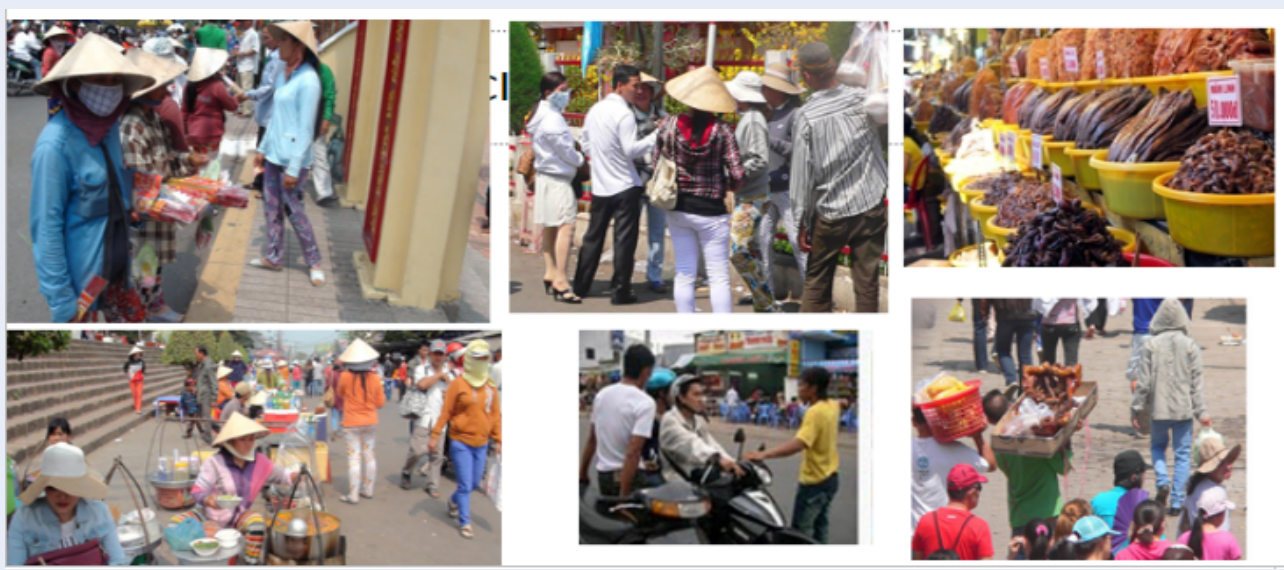

Figure 2: Service in Chau Doc — An Giang. Source: Duong Duc Minh, 2016 - 2018

(Chau Doc) and continue to be promoted. In the exploitation and development of tourism in this spiritual tourism today, although the local authority has made certain efforts, it still has barriers profoundly affecting the goals of stable tourism development of the locality. Because the economic values have emerged but the cultural and sociable values tend to be affected. The focus of Sam mountain complex in the exploitation and development of tourism is a tourism complex of Ba Chua Xu shrine - Thay Tay An Pagoda - Thoai Ngoc Hau Tomb. Bustling scene of the people visiting these worship places is common here. Especially in the high season, from 23 to 27 April according to the lunar calendar when people come here to worship $\mathrm{Ba}$ Chua Xu; on 14 August according to the lunar calendar for worshiping Buddha Thay Tay An, it is difficult for travel in the area because of a huge amount of visitors. Most of the tourists are the Vietnamese people whose spiritual needs are common. There are a few international visitors, which does not express a clear spiritual need. For Vietnamese visitors, their top priority in worship at the above mentioned vestige is $\mathrm{Ba}$ Chua $\mathrm{Xu}$ shrine, the worship at other places are almost done when visitors have more time to visit Sam mountain relic complex.

The visitors are quite various that visitors organize mainly themselves in their families, small groups or individuals. Visitors travel in groups (through travel business - travel company) are few. Visitors come to "praise Ba Chua Xu (praise Mother Land)" with many different purposes, but it is mainly the demand for wealth and quiet life. Especially most people coming 


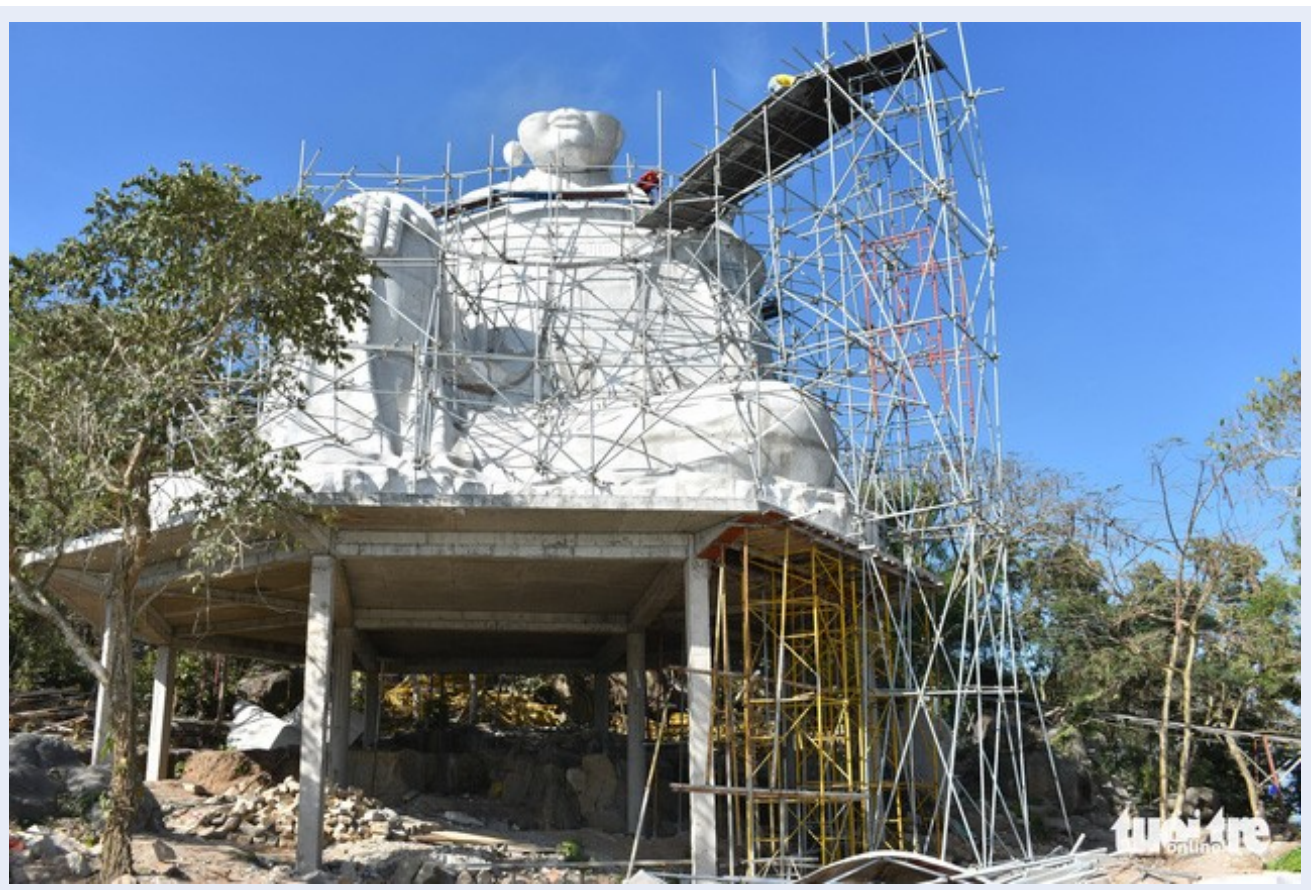

Figure 3: The new statue of Ba Chua Xu. Source: ${ }^{9}$

to "praise Ba Chua $\mathrm{Xu}$ " are traders and businessmen around the country. In the process of "praise Ba Chua $\mathrm{Xu}$ ", traders come to "Get a godsend from Ba Chua $\mathrm{Xu}$ " to do business. Usually, "Get a godsend from $\mathrm{Ba}$ Chua Xu" is at the beginning of the year according to the lunar calendar (from January to April) and at the end of the year, they come for Thanksgiving. Or in some cases, tourists combine Thanksgiving in the previous year and getting a godsend in the new year on the occasion of lunar new year. This combination includes activities such as offering costumes and jewelry to $\mathrm{Ba}$ Chua $\mathrm{Xu}$, the offerings include fruits, fresh flowers, votive papers, roast pork, ... Besides, the visitors also offer cash which is received by the management board of $\mathrm{Ba}$ Chua Xu shrine relic instead and used in restoring, supporting to complete the infrastructure system at the locality and organizing charitable activities or events related to $\mathrm{Ba}$ Chua $\mathrm{Xu}$ shrine.

Funding sources of tourists contributed through serving offerings to enhance their personal merit at $\mathrm{Ba}$ Chua Xu shrine in 2017 is nearly 100 billion $\mathrm{VND}^{\mathrm{f}}$. This amount is used for a variety of purposes in order to improve the life of the communities around the area such as building roads, building schools, assisting the poor, etc.

${ }^{\mathrm{f}}$ Result of interview with The Management Board of Sam Mountain cultural relics and tourism in January 2018
Most visitors are only allowed to worship Ba Chua Xu in the Presbytery, taking photos is not allowed in the space of worship. After the Worshipping Ceremony for the Via Ba Ceremony (Holy Lady Ceremony) on 23 to 27 April in lunar calendar, the number of tourists reduces. In the low season, tourists mainly come on weekends. This greatly affects the business of the units doing business of accommodation, restaurants, supplying worship products in $\mathrm{Ba}$ Chua Xu shrine around the city in particular and in Chau Doc city in general. The policies of price reduction, even some business owners must cover losses due to hiring employees for cleaning motels, inns and still have to hire them to keep them continue to work in the low season. Visitors coming to "Praise $\mathrm{Ba}$ Chua Xu" have a chance to access a various system of providing services from motels, inns, hotels to dining, buying offerings, ... The commodities sold for visitors have various origins: local origin (yellow and flavorful sauce moustached fish danio, blackfish sauce, palm sugar, ...), Thailand origin (tamarind, shoes, green oil, ...). Currently at tourist sites there is a lack of high-quality products in both content and form of packaging bearing the feature of the locality and the surrounding areas.

The interesting thing is the appearance of "a team of consultants for visitors" in selecting services that is the people offering "motorbike taxi" or performing as "service brokers". Through an in-depth interview 
to the service businessmen at Sam Mountain area, an information often appearing is "All things have brokers here"; "We have to cooperate with them (team of service brokers) to have customers". After introducing visitors about the shopping service, "brokers" will receive commissions from the business owners. This form is spontaneous.

Many other spontaneous activities of the people also appear to earn their living such as: peddling (selling herbs, selling local specialties, selling lottery tickets, selling drinks, selling fast food, etc). Even when they introduce visitors to use services from the accommodation business, they automatically become "service brokers". Besides, it sometimes appears freelance fortune-tellers and they also earn a more income to cover their life but they work in avoiding the control of the authorities.

The night services at Sam mountain relic complex are like the daytime ones that have no attractive activities except the Worshipping Ceremony for the Via Ba Ceremony. Even many visitors have no need to stay overnight, they just want to "Praise Ba Chua Xu" and return or move to other destinations in other provinces such as Ha Tien - Phu Quoc (Kien Giang) or continue their journey of spiritual tourism destinations such as Ba Nam Hai Pagoda, Bac Lieu), Ba Thien Hau Temple in Binh Duong, Ba Den Mountain Temple (Tay Ninh)...

The government's interest in investment, planning organization and exploitation to serve the tourism development for Sam mountain in particular makes this relic complex remain the major position to shape Chau Doc city as a cultural tourism urban spirituality. The important issue is parties involving in tourism economy connecting to spiritual tourism in An Giang should be clearly aware of their responsibilities to jointly build and develop a strong spiritual tourism at Sam Mountain relic complex.

Finally, we are going to focus on analysing the impact of tourism in Chau Doc on natural environment.

In December 2006, Chau Doc had accessed to an environmental improvement project implemented by the Urban Environmental Planning Program in Vietnam. With more than 280,000 Euros received from the project, Chau Doc is equipped with garbage cans, toilets. In addition, the local government also built water tanks, installed irrigation systems and planted more trees to improve the environment. Before the implementation of the project, the tourist area was only able to collect about $50 \%$ of the waste - equivalent to 5 tons / day, transporting, manually collecting waste, lack of specialized facilities, no garbage collection station. At the same time, the speed of urbanization reduces the density of natural trees, especially the lack of irrigation system, causing the death of many trees in each dry season. Tourists and local people often litter arbitrarily. Through implementation of the project until 2009, sense of responsibility of the community in environmental protection has been improved, plant 9,000 new trees (Result of interview with Head Office of Culture and Information - Chau Doc People's Committee, June 2018).

Up to this year, the air quality was assessed by the Department of Natural Resources and Environment of An Giang Province as good and no signs of pollution. In general, the quality of the natural environment at Mount Sam is improving. However, on holidays, our observation that tourists' pressure on natural ecosystems is one of the issues that need to be addressed in order to limit negative impacts of tourism development on the environment.

\section{CONCLUSION}

Through the analysis of tourism activities in Chau Doc, we can see that the spiritual tourism has a great potential for development. But the exploitation and development of spiritual tourism only stop at the attraction in terms of quantity but not promote the advantages of destinations to promote the tourism quality in order to increase the revenues. At the same time, more spiritual visitors appearing can put pressures for the destinations and is a major challenge to ensure a capacity problem in tourism. Therefore, the necessary important task is to find a way in exploiting and developing the tourism by improving the quality of services, stimulus for visitors to upgrade the value of spiritual tourism. Relating to this task, works have 
to do are: investigation, survey and assessment of the system of spiritual tourism resources; supply capacity in terms of tourism services; the mechanisms of exploitation and development management policy; human resources and the participation of local communities. The next job is calculating the management of the participation of tourists during the peak season to ensure the capacity. When capacity is guaranteed, it contributes to the preservation of cultural - natural values at the destinations. There are many urgent jobs that need to be implemented, but the said two main responsibilities are the necessary tasks to help the localities to exploit and develop sustainably the spiritual - cultural tourism activities.

Spiritual tourism is developed and implemented extensively in Chau Doc - An Giang. Spiritual tourism is a unique form of expression of the kinds of cultural tourism. Almost in the tour program, there are destinations associated with the works and system of natural landscapes appearing or relating to the cultural and spiritual values. Or in other words, spiritual and cultural values play an important role in attracting visitors and contributing positively to the development of tourism economy in our country. Originating from diverse needs of tourists, current outstanding spiritual tourism activities are visiting and learning about the structures of religious beliefs; attending events relating to the festivals associated with the expression in belief and religion; pilgrimage tourism, meditation tourism; spiritual tourism to commemorate the national hero...

Sustainable development is the discourse which has been advocated by many researchers, many scientists and policy makers around the world and in Vietnam. This discourse appears and becomes a key target in all economic sectors of our country, including tourism. Especially, in An Giang province, spiritual tourism has become one of driving forces of local economy - society and culture. However, in Chau Doc city An Giang province, many tourist services have been formed from the spiritual value with the income of spiritual tourism is not high. At the same time, there are problems that need to be got better of social and environmental field.

From Anthropology approach about sustainable development, from datas are collected through fieldwork and in-depth interviews with stakeholders, this paper focuses on analyzing the practice of spiritual tourism in Chau Doc - An Giang.

\section{CONFLICTS OF INTEREST}

This article does not create conflicts of interest with individuals or organizations, but mainly highlights the findings on the influence of developing tourism on the environment.

\section{AUTHOR CONTRIBUTION}

Authors give a thorough analysis about influence of exploitation and development spiritual tourism to environment (natural and humanity) in Chau Doc - An Giang. For detail:

+ Ta Duy Linh conducted research framework, synthesized overview documents and analyzed the collected database to complete the article.

+ Duong Duc Minh field survey, interviewed with stakeholders, synthesize the materials and coordinated to complete the article.

\section{ACKNOWLEDGMENTS}

This article is funded by the research project at the University of Social Sciences and Humanities - Vietnam National University Ho Chi Minh City (Code: T2018-01).

\section{REFERENCES}

1. Harris D, Moore M, Schmit H, et al. Country Classifications for a Changing World, Institute of Development Studies at the University of Sussex Brighton, UK. 2009;.

2. United Nations. Report of the World Commission on Environment and Development Our Common Future; 1987.

3. Sharpley R. The Myth of Sustainable Tourism, Center For Sustainable Development Working Papers Series 2009/2010 No.4; 2009 .

4. UNEP, UNWTO. Making Tourism More Sustainable - A Guide for Policy Makers. In: Policy Makers; 2005. p. 11.

5. Comunist Party of Vietnam. The Politburou's Resolution 08NQ/TW. 2017;p. 11, 16th January 2017.

6. Office of Culture and Information - Chau Doc People's Committee; 2010.

7. People's Committee of An Giang Province; 2014.

8. Management Board of Sam Mountain Cultural Relics and Tourism; 2014.

9. Dau B. Commit to remove the statue of $\mathrm{Ba}$ Chua $\mathrm{Xu}$, build a statue of Jade Buddha at Sam Mountain. . Tuoi Tre News. 2018; February 12, 2018. Available from: https://tuoitre.vn/cam-ket-do-tuong-ba-chua-xu-xay-tuongphat-ngoc-o-nui-sam-20180228144956644.htm. 


\title{
Ảnh hưởng của việc thực hành du lịch tâm linh đến môi trường tại Châu Đốc - An Giang - Việt Nam
}

\author{
Tạ Duy Linh, Dương Đức Minh*
}

Trương Đại học Khoa học Xã hội và Nhân văn, Đại học Quốc gia Tp.HCM, Việt Nam

\section{Liên hệ}

Dương Đức Minh, Trường Đại học Khoa học Xã hội và Nhân văn, Đại học Quốc gia Tp.HCM, Việt Nam

Email: duongducminh@hcmussh.edu.vn

Lịch sử

- Ngày nhận: 30/11/2018

- Ngày chấp nhận: 04/4/2019

- Ngày đăng: 28/6/2019

DOI:
https://doi.org/10.32508/stdjssh.v3i1.509

\section{Check for updates}

\section{Bản quyền}

(c) ĐHQG Tp.HCM. Đây là bài báo công bố mở được phát hành theo các điều khoản của the Creative Commons Attribution 4.0 International license.

\section{TÓM TẮT}

Châu Đốc là một thành phố của tỉnh An Giang thuộc đồng bằng sông Cửu Long của Việt Nam. Tọa lạc tại Châu Đốc là không gian văn hóa tâm linh núi Sam. Một trong những điểm tham quan du lịch tâm linh nởi bật tại đây là Miếu Bà Chúa Xứ. Hàng năm, điểm tham quan du lịch tâm linh này thu hút từ 3 đến 5 triệu du khách. Với lượng lớn khách du lịch xuất hiện tại quần thể di tích núi Sam, việc thực hành du lịch tâm linh đã có tác động đến môi trường tự nhiên và văn hóa - xã hội. Ảnh hưởng của các bên liên quan đến môi trường (tự nhiên và nhân văn) thông qua việc hưởng thụ và cung ứng dịch vụ du lịch. Các bên liên quan tham gia vào hoạt động du lịch ở Châu Đốc bao gồm: chính quyền địa phương, nhà cung ứng dịch vụ (ẩm thực, vận chuyển và lưu trú, ...) và khách du lịch. Việc thực hành du lịch tâm linh khác với các loại hình du lịch khác. Nhu cầu tâm linh lấn át nhu cầu tận hưởng các dịch vụ du lịch. Với kỳ vọng cải thiện lợi ích kinh tế cho địa phương, dịch vụ du lịch ngày càng được đầu tư và bổ sung. Khi lợi ích kinh tế được quan tâm, các vấn đề bảo tôn các giá trị tự nhiên và văn hóa - xã hội bị hạn chế, tạo ra mối đe dọa có thể gây tổn hại đến môi trường ở Châu Đốc. Do đó, việc khai thác và phát triển du lịch tâm linh tạo ra ảnh hưởng nhất định đến môi trường địa phương. Việc nghiên cứu các tác động của thực hành du lịch tâm linh là cần thiết trong bối cảnh hiện nay. Thông qua khảo sát thực địa, phỏng vấn sâu với các bên liên quan và quan sát tham dự tại các lễ hội văn hóa tâm linh địa phương từ tháng 9 năm 2016 đến tháng 6 năm 2018, bài viết này mô tả và phân tích các đặc điểm của thực hành du lịch tâm linh ở Châu Đốc. Từ đó, các tác giả tìm hiểu ảnh hưởng của việc thực hành du lịch tâm linh đối với môi trường tự nhiên và văn hóa - xã hội của địa phương. Đồng thời, nhóm tác giả đưa ra một khuyến nghị khai thác và phát triển du lịch tâm linh ở Châu Đốc.

Từ khoá: Thực hành du lịch tâm linh, tác động đến môi trường, Châu Đốc - An Giang - Việt Nam

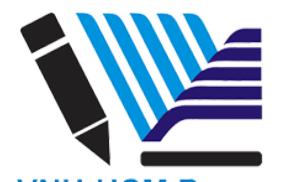

VNU-HCM Press
Trích dẫn bài báo này: Linh T $D$, Minh $D D$ J. Ảnh hưởng của việc thực hành du lịch tâm linh đến môi trường tại Châu Đốc - An Giang - Việt Nam. Sci. Tech. Dev. J. - Soc. Sci. Hum.; 3(1):47-54. 